Article

\title{
Acute Intrathoracic Tuberculosis in Children and Adolescents with Community-Acquired Pneumonia in an Area with an Intermediate Disease Burden
}

Claudia Roya-Pabón 1,2,3 Andrea Restrepo ${ }^{4,5}$, Olga Morales ${ }^{1,2}$, Catalina Arango 1,2, María Angélica Maya 6 Marcela Bermúdez ${ }^{7}$, Lucelly López ${ }^{8}$ (D), Carlos Garcés ${ }^{1}$, Mónica Trujillo ${ }^{4,5,9}$, Luisa Fernanda Carmona ${ }^{10}$, Margarita Rosa Giraldo ${ }^{10}$, Lázaro A. Vélez ${ }^{6,7}$ and Zulma Vanessa Rueda $8,11, *$ (i)

check for updates

Citation: Roya-Pabón, C.; Restrepo, A.; Morales, O.; Arango, C.; Maya,

M.A.; Bermúdez, M.; López, L.;

Garcés, C.; Trujillo, M.; Carmona, L.F.; et al. Acute Intrathoracic

Tuberculosis in Children and

Adolescents with

Community-Acquired Pneumonia in an Area with an Intermediate Disease Burden. Pediatr. Rep. 2022, 14, 71-80. https://doi.org/10.3390/ pediatric14010011

Academic Editor: Maria Chironna

Received: 13 December 2021

Accepted: 20 January 2022

Published: 5 February 2022

Publisher's Note: MDPI stays neutral with regard to jurisdictional claims in published maps and institutional affiliations.

Copyright: (C) 2022 by the authors. Licensee MDPI, Basel, Switzerland. This article is an open access article distributed under the terms and conditions of the Creative Commons Attribution (CC BY) license (https:// creativecommons.org/licenses/by/ $4.0 /)$.
1 Grupo Pediaciencias, Departamento de Pediatría y Puericultura, Universidad de Antioquia UdeA, Medellin 050010, Colombia; clalili@gmail.com (C.R.-P.); olmmunera@yahoo.com (O.M.); catarango52@hotmail.com (C.A.); calichegarces@hotmail.com (C.G.)

2 Departamento de Pediatría, Hospital Universitario San Vicente Fundación, Medellin 050010, Colombia

3 Pima County Health Department, Tuberculosis Clinic, Tucson, AZ 85713, USA

4 Departamento de Pediatría, Hospital Pablo Tobón Uribe, Medellin 050010, Colombia; avrestrepo33@gmail.com (A.R.); trupitv@gmail.com (M.T.)

5 Departamento de Pediatría, Universidad CES, Medellin 050010, Colombia

6 Unidad de Enfermedades Infecciosas, Hospital Universitario San Vicente Fundación, Medellin 050010, Colombia; mangelicamaya@gmail.com (M.A.M.); lazarovelezg@gmail.com (L.A.V.)

7 Grupo Investigador de Problemas en Enfermedades Infecciosas (GRIPE), Facultad de Medicina, Universidad de Antioquia UdeA, Medellin 050010, Colombia; marcelita8510@gmail.com

8 Grupo de Investigación en Salud Pública, Facultad de Medicina, Universidad Pontificia Bolivariana, Medellin 050031, Colombia; lucellyl@gmail.com

9 Section of Pediatric Infectious Diseases, Clínica Universitaria Bolivariana, Medellin 050010, Colombia

10 Secretaría Seccional de Salud y Protección Social de Antioquia, Gobernación de Antioquia, Medellin 050010, Colombia; lufe2346@hotmail.com (L.F.C.); giralrosita@gmail.com (M.R.G.)

11 Department of Medical Microbiology and Infectious Diseases, University of Manitoba, Winnipeg, MB R3E 0J9, Canada

* Correspondence: zulmaruedav@gmail.com; Tel.: +1-204-789-3678

Abstract: Tuberculosis (TB) in the pediatric population is a major challenge. Our objective was to describe the clinical and microbiological characteristics, radiological patterns, and treatment outcomes of children and adolescents (from 1 month to 17 years) with community-acquired pneumonia (CAP) caused by TB. We performed a prospective cohort study of a pediatric population between 1 month and 17 years of age and hospitalized in Medellin, Colombia, with the diagnosis of radiologically confirmed CAP that had $\leq 15$ days of symptoms. The mycobacterial culture of induced sputum was used for the bacteriological confirmation; the history of TB contact, a tuberculin skin test, and clinical improvement with treatment were used to identify microbiologically negative TB cases. Among 499 children with CAP, TB was diagnosed in 12 (2.4\%), of which 10 had less than 8 days of a cough, 10 had alveolar opacities, 9 were younger than 5 years old, and 2 had close contact with a TB patient. Among the TB cases, 50\% (6) had microbiological confirmation, 8 had viral and/or bacterial confirmation, one patient had multidrug-resistant $\mathrm{TB}$, and 10/12 had non-severe pneumonia. In countries with an intermediate TB burden, Mycobacterium tuberculosis should be included in the etiological differential diagnosis (as a cause or coinfection) of both pneumonia and severe CAP in the pediatric population.

Keywords: cohort study; children; adolescents; community-acquired pneumonia; intrathoracic tuberculosis; acute tuberculosis

\section{Introduction}

A tuberculosis (TB) diagnosis in children is a major challenge due to the difficulty of obtaining appropriate samples, the low microbiological yield, and the limitation of the 
clinical definitions that require more than 2 weeks of signs/symptoms to be suggestive of tuberculosis (persistent $>2$ weeks, unremitting cough, weight loss/failure to thrive, persistent unexplained fever, persistent unexplained lethargy, or decrease in playfulness/activity reported by the parent/caregiver) [1]. However, this clinical definition may be a late approach to diagnosing TB.

When pulmonary TB presents as an acute illness, it is indistinguishable from communityacquired pneumonia (CAP) caused by other pathogens [2]. This often leads to a delay in diagnosis with increased TB morbidity and mortality [3].

Colombia is a tuberculosis endemic country with an intermediate burden (20.88/100,000 cases per population/year). In 2020, a total of 11,390 cases were reported, with an incidence in children under 15 years of $2.7 \%$, and of these, $39.3 \%$ corresponding to children under 5 years of age [4].

CAP continues to be the leading cause of mortality in children under 5 years of age in low- and middle-income countries [5]. The most recently published studies have revealed that, in these children, CAP is caused by viruses $(61-66 \%)$, bacteria $(27 \%)$, atypical bacteria (7.2-20\%), and Mycobacterium tuberculosis (M. tb) (2.9-5.9\%) [6-10]. Furthermore, the coinfection of viruses and bacteria is not infrequent $[6-8,11]$.

Like CAP, TB is also an important cause of illness and death worldwide, despite being a preventable and curable disease. In 2020, there were a total of 9.9 million TB disease cases worldwide, with 1,089,000 occurring in children, showing a mortality of $16 \%$ [12]. A systematic review of patients with severe pneumonia in children under 5 years of age in countries with a high burden of TB found $7.5 \%$ with confirmed cases of acute-onset TB [13]. Most of those studies were conducted in countries with a high HIV prevalence. Oliwa et al. [13] highlight that "previous studies of pneumonia in infants and young children might have underestimated the contribution of tuberculosis as a direct cause or comorbidity of acute community-acquired pneumonia in children because of the difficulties of microbiological confirmation in this age group in resource-restricted tuberculosis endemic settings".

Our goal was to describe the clinical characteristics, radiological patterns, microbiological features, and treatment outcomes in the pediatric population of between 1 month and 17 years old with CAP caused by M.tb in an intermediate TB burden country with a low HIV prevalence.

\section{Materials and Methods}

Study type: Prospective cohort study.

Study population: We included a pediatric population of between 1 month and 17 years of age with a diagnosis of community-acquired pneumonia that required hospitalization in 13 institutions of medium- and high-complexity care from Medellín, Bello, Envigado, Itaguí, Colombia.

Inclusion criteria: Children and adolescents with a diagnosis of CAP and with respiratory symptoms $\leq 15$ days duration. CAP was defined as the presence of lung opacities (alveolar or interstitial) on a chest X-ray and one of the following symptoms or signs: axillary fever $\geq 38.3^{\circ} \mathrm{C}$; tachypnea according to the age of the patient; the finding of rhonchus and/or rales and/or wheezing on auscultation.

Exclusion criteria: Children and adolescents hospitalized in the last 15 days, patients with previous antibiotic treatment for more than $72 \mathrm{~h}$ at the time of hospital admission, patients with primary or severe acquired immunodeficiency, cystic fibrosis, bronchiolitis obliterans, neurological (including cerebral palsy) or neuromuscular disorders, psychiatric disorders that did not allow the patient to assent, congenital metabolic disorders, bronchiolitis (first sibilant episode in children less than 2 years), hematological malignancies, neutropenia $\left(<500\right.$ cells $\left./ \mathrm{mm}^{3}\right)$, primary ciliary dyskinesia, acute immunodeficiency syndrome (AIDS) or HIV infection with a CD4 count of less than 15\% in children of 5 years or younger, or a CD4 cell count $<200$ cells $/ \mathrm{mm}^{3}$ in children older than 5 years, treatment with prednisolone $\geq 1 \mathrm{mg} / \mathrm{kg}$ /day or its equivalent for more than 8 days, or other 
immunosuppressive drugs such as cyclosporine, methotrexate, mycophenolate mofetil, cyclophosphamide, azathioprine, and fluorouracil.

Patient enrollment: Between August 2011 and September 2012, children and adolescents with CAP admitted through the pediatric emergency room and requiring hospitalization in 13 participating institutions.

Ethics approval: This study was approved by the Ethics Committee of the Medical School of the Universidad de Antioquia and by each participating institution. All parents or legal guardians and the child were asked to voluntarily participate in the study, and after explaining its purpose, informed consent was signed by the parents (legal guardians) and informed assent was obtained in children $>7$ years old. All patients had the same access to health care and received treatment according to the standard of care.

Procedures and laboratory tests: Patient enrollment was carried out by general practitioners trained by the study investigators following standardized procedures. Children and adolescents who met the inclusion criteria and did not meet any exclusion criteria were enrolled. The data collected for each patient included sociodemographic, clinical, and laboratory information, history of TB exposure, past medical history, previous immunizations or treatments; these were filled out in a data collection form designed by the investigators.

Severe pneumonia was classified according to the World Health Organization (WHO) classification of childhood pneumonia, i.e., non-severe (pneumonia): fast breathing; severe: chest indrawing; very severe: not able to drink, persistent vomiting, convulsions, lethargic or unconscious, stridor in a calm child, or severe malnutrition.

A trained nurse administered the tuberculin skin test (Tuberculin PPD RT-23, SSI 2 T.U/0.1 mL, Statens Serum Institut ${ }^{\circledR}$, Copenhagen, Denmark) to all accepted children and adolescents, according to CDC guidelines. The reading was performed 48 to $72 \mathrm{~h}$ later and measured in millimeters of induration.

A chest $\mathrm{X}$-ray was obtained for each patient, and readings were performed by the radiologists of each institution.

A blood sample (for aerobic bacterial culture and serology for atypical microorganisms), a urine sample (for Streptococcus pneumoniae and Legionella pneumophila antigens), and 3 induced sputum (IS) samples (for viruses, pyogenic bacteria, and M.tb) were collected from each patient.

IS was obtained after inhalation of $\beta-2$ agonist $(200 \mu \mathrm{g})$ and nebulization of $5 \%$ hypertonic saline. IS samples were collected by nasopharyngeal aspirate (children younger than 5 years) or by generating a cough through forced expiration and assisted coughing. Sputum induction was a procedure that was performed in all ages. Continuous monitoring before, during, and one hour after the procedure was performed, and no complications were recorded.

Additionally, a nasopharyngeal swab was collected for viral detection with direct and indirect immunofluorescence for Bordetella pertussis.

One of the IS samples was stained with auramine-rhodamine and inoculated in solid and liquid cultures for M. $t b$ (Löwenstein-Jensen, thin-layer agar, and BD Bactec ${ }^{\mathrm{TM}}$ MGIT тм 960, Sparks, MD, USA). The samples were transported at $2-8{ }^{\circ} \mathrm{C}$ to the laboratory. The IS and NS samples were stored at $-80^{\circ} \mathrm{C}$ until processing.

In addition to the case definition of $\mathrm{CAP}$, the following definitions were applied for intrathoracic TB. Microbiologically confirmed TB was defined as a positive culture for $M$. Tb. TB without microbiological confirmation: culture negative for $M . t b$ and history of household or close contact with a confirmed TB case or immunological evidence of previous exposure to $M . t b$ (positive PPD $\geq 10 \mathrm{~mm}$ ) and an adequate clinical response to the TB treatment.

The follow-up on the children and adolescents with CAP included in the study was conducted by pediatric pulmonologists.

One month after discharge from the hospital, an additional evaluation was performed by a pediatric infectious disease specialist in those patients with suspected or confirmed TB as well as those with a diagnosis of latent tuberculosis infection to rule out TB. 
In addition, a follow-up phone call was made by the medical and nursing team hired by this research project at 3,6 , and 12 months after recruitment.

Statistical analysis: The data were included in a database designed in Microsoft Access ${ }^{\circledR}$ 2007, version 12.0, and then exported to an SPSS ${ }^{\circledR}$ version 22 for analysis. To summarize the variables, absolute and percentage frequencies were used.

\section{Results}

The study evaluated 1410 children and adolescents, and 525 met the inclusion criteria. Among them, 26 patients were excluded because they did not have all the TB tests (Figure 1).



Figure 1. Flow chart of included patients.

Among the 499 children and adolescents with CAP and complete TB tests, 12 were diagnosed with intrathoracic TB and 13 with a latent TB infection (LTBI). Those with intrathoracic $\mathrm{TB}$ were referred by the study investigators to their pediatricians and the local TB control program to start treatment and to perform a TB contact tracing investigation. All patients in the study had received BCG at birth, and none of them had HIV.

In patients with intrathoracic TB, the median age was 3 years, and $75 \%(9 / 12)$ were younger than 5 years. Most patients with intrathoracic TB had less than 8 days of a cough $(83.3 \%, 10 / 12), 16.7 \%(2 / 12)$ had a history of being a close contact with a TB case, one had diabetes mellitus (DM) $(8.3 \%)$, and one had malnutrition (8.3\%). In addition, $83.3 \%(10 / 12)$ of the TB cases had non-severe pneumonia, 33.3\% (4/12) had a history of previous CAP episodes before the current one, 83.3\% (10/12) had low socio-economic status, and 16.7\% had oxygen saturation below $90 \%$ (Table 1 ). 
Table 1. Baseline characteristics of children and adolescents with intrathoracic TB and communityacquired pneumonia.

\begin{tabular}{|c|c|c|}
\hline Variables & $\begin{array}{l}\text { Children and Adolescents with CAP } \\
\text { and Intrathoracic TB } \\
\text { N =12 (\%) }\end{array}$ & $\begin{array}{l}\text { Children and Adolescents with CAP } \\
\text { without Intrathoracic TB } \\
\text { N }=487(\%)\end{array}$ \\
\hline $\begin{array}{l}\text { Female } \\
\text { Children } \leq 5 \text { years of age } \\
\text { Children }>5 \text { years of age } \\
\text { Prior antibiotic use }\end{array}$ & $\begin{array}{l}9(75) \\
9(75) \\
3(25)\end{array}$ & $\begin{array}{l}236(48.5) \\
409(84.0) \\
78(16)\end{array}$ \\
\hline $\begin{array}{ll}\text { - } & \text { Last } 3 \text { months } \\
\text { - } & \text { Last } 48 \mathrm{~h}\end{array}$ & $\begin{array}{l}1(8.3) \\
2(16.7)\end{array}$ & $\begin{array}{l}115(23.8) \\
34(7.0)\end{array}$ \\
\hline $\begin{array}{l}\text { Close TB contact case } \\
\text { Cough } \\
\text { Cough }<8 \text { days } \\
\text { Fever } \\
\text { Irritability } \\
\text { Chest pain } \\
\text { Severity of pneumonia * }\end{array}$ & $\begin{array}{l}2(16.7) \\
12(100) \\
9(75) \\
12(100) \\
7(58.3) \\
5(41.7)\end{array}$ & $\begin{array}{l}17(3.5) \\
476(97.7) \\
332(68.2) \\
452(92.8) \\
222(45.6) \\
120(24.6)\end{array}$ \\
\hline $\begin{array}{ll}- & \text { Non-severe } \\
\text { - } & \text { Severe } \\
\text { - } & \text { Very severe }\end{array}$ & $\begin{array}{l}10(83.3) \\
2(16.7) \\
0(0)\end{array}$ & $\begin{array}{l}357(73.3) \\
115(23.6) \\
15(3.1)\end{array}$ \\
\hline Radiological abnormalities & & \\
\hline $\begin{array}{ll}\text { - } & \text { Alveolar opacities } \\
\text { - } & \text { Interstitial opacities } \\
\text { - } & \text { Pleural effusion }\end{array}$ & $\begin{array}{l}10(83.33) \\
5(41.66) \\
1(8.33)\end{array}$ & $352(70.54) 258(51.70) 24(4.80)$ \\
\hline $\begin{array}{l}\text { Coinfections } \\
\text { Comorbidities } \\
\text { Asthma }\end{array}$ & $8(66.7)$ & $172(35.3)$ \\
\hline $\begin{array}{ll}\text { - } & \text { Low birth weight } \\
\text { - } & \text { Diabetes mellitus } \\
\text { - } & \text { Malnutrition }\end{array}$ & $\begin{array}{l}1(8.3) \\
2(16.7) \\
1(8.3) \\
1(8.3)\end{array}$ & $\begin{array}{l}135(27.8) \\
56(11.6) \\
1(0.2) \\
52(10.7)\end{array}$ \\
\hline $\begin{array}{l}\text { History of CAP } \\
\text { Low socio-economic status } \\
\text { Oxygen saturation below } 90 \%\end{array}$ & $\begin{array}{l}4(33.3) \\
10(83.3) \\
2(16.7)\end{array}$ & $\begin{array}{l}129(26.6) \\
366(78.5) \\
165(33.9)\end{array}$ \\
\hline
\end{tabular}

CAP: community-acquired pneumonia; TB: tuberculosis; low socio-economic status: Colombia classified people according to their income in 6 categories, stratum 1 being the lowest income and 6 the highest income. This variable includes strata 1,2, and 3. * Severity of pneumonia: non-severe (pneumonia): fast breathing; severe: chest indrawing; very severe: not able to drink, persistent vomiting, convulsions, lethargic or unconscious, stridor in a calm child, or severe malnutrition.

The diagnosis of intrathoracic TB was made by a bacteriological confirmation in IS culture for 50\% (6/12) of cases and one patient had multidrug-resistant TB (MDR-TB). Alveolar opacities were the most frequent radiological abnormalities (83.3\%). Of the 12 patients with intrathoracic $\mathrm{TB}$, eight had coinfections and six had more than two pathogens (Table 2). TB treatment was well tolerated by all children and adolescents. During the follow-up, $83.3 \%$ (10/12) finished TB treatment and showed clinical improvement. Two children were lost to follow-up. None of the patients died (Table 2). 
Table 2. Radiological, epidemiological, tuberculin skin test, and microbiological characteristics in 12 children and adolescents with community-acquired pneumonia and intrathoracic TB.

\begin{tabular}{|c|c|c|c|c|c|c|c|c|}
\hline Case & Age & $\begin{array}{l}\text { Close Contact } \\
\text { with TB Case }\end{array}$ & TST (mm) & $\begin{array}{l}\text { Radiological } \\
\text { Abnormalities }\end{array}$ & $\begin{array}{l}\text { Microbiological } \\
\text { (Culture) }\end{array}$ & $\begin{array}{l}\text { Coinfections } \\
\text { during CAP } \\
\text { Onset }\end{array}$ & Severity & Follow-Up \\
\hline 1 & 1 у.о. & Negative & $\begin{array}{l}\text { Administered, } \\
\text { but problems } \\
\text { with TST } \\
\text { reading }\end{array}$ & $\begin{array}{c}\text { Lobar } \\
\text { consolidation } \\
\text { and } \\
\text { diffuse } \\
\text { interstitial } \\
\text { opacities }\end{array}$ & Positive & $\begin{array}{l}\text { Respiratory } \\
\text { syncytial } \\
\text { virus and } \\
\text { influenza } \\
\text { virus }\end{array}$ & Severe & $\begin{array}{c}\text { Clinical } \\
\text { improvement } \\
\text { until last } \\
\text { follow-up, } \\
\text { lost in the second } \\
\text { month after TB } \\
\text { treatment started }\end{array}$ \\
\hline 2 & 1 у.о. & Negative & 0 & $\begin{array}{c}\text { Focal } \\
\text { interstitial } \\
\text { opacity }\end{array}$ & Positive & $\begin{array}{c}\text { Rhinovirus } \\
\text { and Coxiella } \\
\text { burnetii }\end{array}$ & Non-severe & $\begin{array}{l}\text { Completed } \\
\text { treatment } \\
\text { Clinical } \\
\text { improvement }\end{array}$ \\
\hline 3 & 1 у.о. & Negative & 0 & $\begin{array}{c}\text { Lobar } \\
\text { consolidation }\end{array}$ & Positive & $\begin{array}{l}\text { Streptococcus } \\
\text { pneumoniae } \\
\text { and } \\
\text { Mycoplasma } \\
\text { pneumoniae } \\
\text { and } \\
\text { Bordetella } \\
\text { pertussis and } \\
\text { Coronavirus }\end{array}$ & Non-severe & $\begin{array}{c}\text { MDR-TB, } \\
\text { completed } \\
\text { treatment } \\
\text { Clinical } \\
\text { improvement }\end{array}$ \\
\hline 4 & 2 y.o. & Positive & 13 & $\begin{array}{c}\text { Focal interstitial } \\
\text { opacity }\end{array}$ & Positive & $\begin{array}{c}\text { Rhinovirus } \\
\text { and } \\
\text { Moraxella } \\
\text { catarrhalis }\end{array}$ & Non-severe & $\begin{array}{l}\text { Completed } \\
\text { treatment } \\
\text { Clinical } \\
\text { improvement, }\end{array}$ \\
\hline 5 & 2 y.o. & Negative & 0 & $\begin{array}{c}\text { Lobar } \\
\text { consolidation }\end{array}$ & Positive & $\begin{array}{l}\text { Parainfluenza } \\
\text { and } \\
\text { influenza } \\
\text { virus }\end{array}$ & Non-severe & $\begin{array}{l}\text { completed } \\
\text { treatment } \\
\text { Clinical } \\
\text { improvement }\end{array}$ \\
\hline 6 & 14 y.o. & Negative & 17 & $\begin{array}{c}\text { Lobar } \\
\text { consolidation }\end{array}$ & Positive & $\begin{array}{l}\text { Moraxella } \\
\text { catarrhalis }\end{array}$ & Non-severe & $\begin{array}{c}\text { Completed } \\
\text { treatment } \\
\text { Clinical } \\
\text { improvement, } \\
\text { completed }\end{array}$ \\
\hline 7 & 2 y.o. & Negative & 16 & $\begin{array}{c}\text { Diffuse } \\
\text { consolidation }\end{array}$ & Negative & No & Severe & $\begin{array}{l}\text { treatment } \\
\text { Clinical } \\
\text { improvement, }\end{array}$ \\
\hline 8 & 3 y.o. & Negative & 16 & $\begin{array}{c}\text { Lobar } \\
\text { consolidation }\end{array}$ & Negative & No & Non-severe & $\begin{array}{c}\text { completed } \\
\text { treatment } \\
\text { Clinical } \\
\text { improvement, }\end{array}$ \\
\hline 9 & 4 y.o. & Negative & 13 & $\begin{array}{c}\text { Lobar } \\
\text { consolidation }\end{array}$ & Negative & $\begin{array}{l}\text { Streptococcus } \\
\text { pneumoniae }\end{array}$ & Non-severe & $\begin{array}{c}\text { lost, no treatment } \\
\text { completion data } \\
\text { Clinical } \\
\text { improvement } \\
\text { until last } \\
\text { follow-up, }\end{array}$ \\
\hline 10 & 4 y.o. & Positive & 15 & $\begin{array}{c}\text { Lobar } \\
\text { consolidation } \\
\text { and focal } \\
\text { interstitial } \\
\text { opacity } \\
\text { Diffuse }\end{array}$ & Negative & No & Non-severe & $\begin{array}{c}\text { completed } \\
\text { treatment } \\
\text { Clinical } \\
\text { improvement }\end{array}$ \\
\hline 11 & 10 y.o. & Negative & 20 & $\begin{array}{l}\text { consolidation } \\
\text { and diffuse } \\
\text { interstitial } \\
\text { opacities and } \\
\text { pleural effusion }\end{array}$ & Negative & No & Non-severe & $\begin{array}{l}\text { Completed } \\
\text { treatment } \\
\text { Clinical } \\
\text { improvement }\end{array}$ \\
\hline 12 & 12 y.o. & Negative & 17 & $\begin{array}{c}\text { Lobar } \\
\text { consolidation }\end{array}$ & Negative & $\begin{array}{l}\text { Influenza } \\
\text { virus } \\
\text { and } \\
\text { Mycoplasma } \\
\text { pneumoniae }\end{array}$ & Non-severe & $\begin{array}{l}\text { Completed } \\
\text { treatment } \\
\text { Clinical } \\
\text { improvement }\end{array}$ \\
\hline
\end{tabular}


Of the 13 patients with LTBI, 11 were eligible to receive latent tuberculosis infection (LTBI) treatment but only five of them received it. Among the reasons for not receiving LTBI treatment were: four patients' mothers did not accept LTBI treatment for their children, two because their primary physician disagreed with the treatment, one had an administrative barrier, and one was lost at follow-up. All patients tolerated the treatment well, and none developed intrathoracic TB during the follow-up.

\section{Discussion}

Despite the fact that Colombia has an intermediate TB burden, an incidence of pediatric CAP due to TB has not been reported. In our study, the incidence of TB in patients with CAP was $2.4 \%$. In other reports by authors in countries with a high burden of TB, the incidence varies between $2.9 \%$ and $5.9 \%$ [6,10]. An incidence as high as $18.9 \%$ has been reported in patients with severe CAP in Uganda [3]. This resulted in a recommendation to rule out TB in every patient with severe CAP in that country. The above finding can be explained by the fact that Uganda is a country with a high TB burden (200 cases/100,000 population) and with a high prevalence of HIV infection $[3,12]$. In our study, none of the children had an HIV infection when TB was diagnosed, and 83.3\% (10/12) of the TB cases had non-severe CAP. Therefore, $M . t b$ should be considered as a CAP pathogen even in non-severe cases.

We found no clinical or radiological differences between children and adolescents with CAP with TB and patients with CAP caused by other pathogens, similar to what was reported in a systematic review of cases from endemic countries with a high burden of TB [13].

Although in our study only two cases of intrathoracic TB had a history of known close contact with confirmed TB, it is extremely important to obtain a history of exposure to people with TB in children and adolescents presenting with CAP. TB exposure is a high-risk factor for developing a TB disease, as demonstrated by Martinez et al. [14], who found that exposed children had a 2-year cumulative risk of developing TB disease from 5.2\% to 7.6\%, and Nantongo et al. [3,14], who described that children with a history of exposure to a smear-positive TB patient in the past year were three times more likely to develop TB [2,13].

There are well-known risk factors strongly related to the progression from infection to TB disease, such as young patients $<5$ years of age caused by an immature immune system and comorbidities such as DM and malnutrition present in our study, which in turn predispose patients to an acute form of the disease [15]. In our study, children younger than 5 years represented the majority of intrathoracic TB cases (75\%), and two cases with severe disease belonged to this age group. Thus, early diagnosis and treatment of TB is important, especially in young children [16] who are at greater risk of a severe disease and more complications.

Our study did not find any symptoms/signs suggestive of TB [1] in patients with CAP and TB. With our findings, we also want to open a debate into whether it is time to change the clinical definitions of tuberculosis in children and adolescents, as it has been reported in adults that up to $77.6 \%$ of people with TB are asymptomatic [17]. Cavallazzi et al. [18] reported $60(0.86 \%)$ patients with TB in a study of 6976 adults with CAP. The authors describe five clinical findings that could predict TB in patients presented with CAP: night sweats, hemoptysis, weight loss, previous exposure to TB, and pulmonary opacities in the upper lobes. Nonetheless, the first three clinical findings do not usually apply to a pediatric population because children with TB do not always have these symptoms, and the most common history is of no weight gain, failure to thrive, and decreased level of activity [16].

Microbiological confirmation of intrathoracic TB was achieved in $1.2 \%(6 / 499)$ of cases with CAP by collecting adequate samples of IS. Other reports describe a $5-8 \%$ microbiological confirmation with IS and/or gastric aspirates, this being as high as $15 \%$ in places with a high burden of TB $[6,19]$. In addition, we had one case with MDR-TB, which alerted us to the presence of these cases in our population and highlighted the importance of having ongoing epidemiological surveillance and always pursuing microbiological confirmation 
in children despite the difficulties due to their paucibacillary nature and the challenge of collecting specimens in young patients.

In the last few years, there has been more insight into the role of coinfections with $M . t b$ to influence the immune response, whether predisposing the person to acquire the infection, in disease progression, or by determining the severity or the capacity to control the disease $[13,20,21]$. In our study one patient had severe CAP, intrathoracic TB, and viral coinfection. In a systematic review by Oliwa et al. [13], TB coinfection with other pathogens had more severe clinical presentations and worse outcomes, including mortality. In our study, we found viral and/or bacterial coinfections in $66.6 \%(8 / 12)$ of the cases and none of them had severe pneumonia and none died. In these cases, TB could be present as a subclinical disease [22] where the acute symptoms are due to the other microorganism or as a case of a clinical TB disease.

A recent systematic review and individual participant meta-analysis continue to confirm that the risk of developing TB among exposed infants and young children is very high (19\%). The majority $(83 \%)$ of these children who developed a TB infection progressed to TB disease in the first 90 days [14]. In our study, 45\% (5/11) of the patients with LTBI were younger than 5 years of age and did not receive any LTBI treatment. Therefore, we consider LTBI treatment as a key intervention to control TB from an early stage that must be administered without delay.

One limitation of our study was that we only collected one IS sample as we did not expect to find $\mathrm{TB}$ cases as a cause of acute $\mathrm{CAP}$, and molecular tests were not available at the time when the study was conducted, which probably would have increased the cases of TB or confirmed those with a negative culture [23].

\section{Conclusions}

In countries with an intermediate TB burden, $M . t b$ should be included in the etiological differential diagnosis (as a cause or coinfection) of both severe and non-severe CAP in children and adolescents. We invite researchers and clinicians around the world to debate whether the current clinical definitions of TB in children may be a late approach to diagnosing $\mathrm{TB}$ as it has been documented in adults that up to $77.6 \%$ of people with $\mathrm{TB}$ are asymptomatic [17]. It is important to conduct more research in children with CAP that includes a systematic search for M.tb, including molecular testing, in countries with an intermediate TB burden as well as develop screening tools that allow identifying incipient and sub-clinical TB [22] in children.

Author Contributions: Conceptualization, C.R.-P., A.R., O.M., C.G., M.T., L.A.V., Z.V.R.; methodology, L.A.V., Z.V.R.; formal analysis, L.L., Z.V.R.; investigation, C.R.-P., A.R., O.M., C.A., M.B., C.G., M.T.; data curation, L.L.; writing—original drat preparation, C.R.P., A.R., O.M., C.A., M.A.M., L.A.V., Z.V.R.; writing—review and editing, M.B., L.L., M.T., L.F.C., M.R.G.; visualization, L.L., Z.V.R.; project administration, Z.V.R.; funding acquisition, L.A.V. All authors have read and agreed to the published version of the manuscript.

Funding: This study was funded by the Colombian Administrative Department of Science, Technology and Innovation-Colciencias, currently MinCiencias, grant number: 111551929199, and Universidad de Antioquia. The funders had no role in the study design, data collection and analysis, decision to publish, or preparation of the manuscript.

Institutional Review Board Statement: This study was approved by the Ethics Committee of the Medical School of the Universidad de Antioquia and by each participating institution.

Informed Consent Statement: Informed consent was obtained from all subjects involved in the study. All parents or legal guardians signed a written consent form, and children over 7 years of age signed a written assent form. All children had the same access to health care and received treatment according to a standard of care.

Data Availability Statement: The data presented in this study are available on request from the corresponding author. The data are not publicly available due to at the time we conducted the study, we did not request to the parents written permission to share the data in publicly accessible repository. 


\begin{abstract}
Acknowledgments: We want to thank Ana María Hernández, Antonio Macías, Dimas Bermúdez, and Santiago Giraldo for their hard work to recruit and follow-up all children participating in the study. Thanks to María Cecilia Oquendo, Carlos Muskus, Diego Bastidas, Enith Knuth, Alejandro Díaz, Marta Morales, Marta Valencia, Juan Gonzalo Mesa, and Isabel Cristina Vallejo. Thanks to Lina Ruiz, Lizeth Urrea, Sara Mejía, and Sebastian Osorio. In addition, thanks to all participating institutions for their support with the study. To all children and their families for agreeing to participate in the study. Finally, to all hospitals that approved the execution of this research: E.S.E. Metrosalud Unidad Hospitalaria San Javier, Clínica Infantil Santa Ana, Clínica Sagrado Corazón, Clínica León XIII, Hospital Universitario San Vicente Fundación, Hospital General de Medellín, Hospital Pablo Tobón Uribe, Clínica Las Américas, Hospital San Rafael de Itagüí, Clínica CES, Hospital Marco Fidel Suárez, Clínica SOMA, and Hospital Manuel Uribe Ángel.
\end{abstract}

Conflicts of Interest: The authors declare no conflict of interest.

\title{
References
}

1. Graham, S.M.; Cuevas, L.E.; Jean-Philippe, P.; Browning, R.; Casenghi, M.; Detjen, A.K.; Gnanashanmugam, D.; Hesseling, A.C.; Kampmann, B.; Mandalakas, A.; et al. Clinical Case Definitions for Classification of Intrathoracic Tuberculosis in Children: An Update. Clin. Infect. Dis. 2015, 61, S179-S187. [CrossRef] [PubMed]

2. Schlossberg, D. Acute Tuberculosis. Infect. Dis. Clin. North Am. 2010, 24, 139-146. [CrossRef] [PubMed]

3. Nantongo, J.M.; Wobudeya, E.; Mupere, E.; Joloba, M.; Ssengooba, W.; Kisembo, H.N.; Lubega, I.R.; Musoke, P.M. High Incidence of Pulmonary Tuberculosis in Children Admitted with Severe Pneumonia in Uganda. BMC Pediatr. 2013, 13, 16. [CrossRef] [PubMed]

4. Instituto Nacional de Salud Informe del Evento Preliminar de Tuberculosis Hasta el Período Epidemiológico XIII Colombia. 2017. Available online: http:/ / www.ins.gov.co/buscador-eventos/SitePages/Evento.aspx?Event=7 (accessed on 13 February 2018).

5. Liu, L.; Oza, S.; Hogan, D.; Chu, Y.; Perin, J.; Zhu, J.; Lawn, J.E.; Cousens, S.; Mathers, C.; Black, R.E. Global, Regional, and National Causes of under-5 Mortality in 2000-15: An Updated Systematic Analysis with Implications for the Sustainable Development Goals. Lancet 2016, 388, 3027-3035. [CrossRef]

6. Pneumonia Etiology Research for Child Health (PERCH) Study Group. Causes of Severe Pneumonia Requiring Hospital Admission in Children without HIV Infection from Africa and Asia: The PERCH Multi-Country Case-Control Study. Lancet 2019, 394, 757-779. [CrossRef]

7. Zar, H.J.; Barnett, W.; Stadler, A.; Gardner-Lubbe, S.; Myer, L.; Nicol, M.P. Aetiology of Childhood Pneumonia in a Well Vaccinated South African Birth Cohort: A Nested Case-Control Study of the Drakenstein Child Health Study. Lancet Respir. Med. 2016, 4 , 463-472. [CrossRef]

8. Bhuiyan, M.U.; Snelling, T.L.; West, R.; Lang, J.; Rahman, T.; Granland, C.; de Gier, C.; Borland, M.L.; Thornton, R.B.; Kirkham, L.A.S.; et al. The Contribution of Viruses and Bacteria to Community-Acquired Pneumonia in Vaccinated Children: A Case-Control Study. Thorax 2019, 74, 261-269. [CrossRef]

9. Nascimento-Carvalho, C.M.; Xavier-Souza, G.; Vilas-Boas, A.-L.; Fontoura, M.-S.H.; Barral, A.; Puolakkainen, M.; Ruuskanen, O.; PNEUMOPAC-Efficacy Study Group. Evolution of Acute Infection with Atypical Bacteria in a Prospective Cohort of Children with Community-Acquired Pneumonia Receiving Amoxicillin. J. Antimicrob. Chemother. 2017, 72, 2378-2384. [CrossRef]

10. Martinez, L.; le Roux, D.M.; Barnett, W.; Stadler, A.; Nicol, M.P.; Zar, H.J. Tuberculin Skin Test Conversion and Primary Progressive Tuberculosis Disease in the First 5 Years of Life: A Birth Cohort Study from Cape Town, South Africa. Lancet Child Adolesc. Health 2018, 2, 46-55. [CrossRef]

11. Seidenberg, P.; Mwananyanda, L.; Chipeta, J.; Kwenda, G.; Mulindwa, J.M.; Mwansa, J.; Mwenechanya, M.; Wa Somwe, S.; Feikin, D.R.; Haddix, M.; et al. The Etiology of Pneumonia in HIV-Infected Zambian Children: Findings From the Pneumonia Etiology Research for Child Health (PERCH) Study. Pediatr. Infect. Dis. J. 2021, 40, S50-S58. [CrossRef]

12. World Health Organization. Global Tuberculosis Report 2021; World Health Organization: Geneva, Switzerland, 2021; ISBN 978-92-4-003702-1.

13. Oliwa, J.N.; Karumbi, J.M.; Marais, B.J.; Madhi, S.A.; Graham, S.M. Tuberculosis as a Cause or Comorbidity of Childhood Pneumonia in Tuberculosis-Endemic Areas: A Systematic Review. Lancet Respir. Med. 2015, 3, 235-243. [CrossRef]

14. Martinez, L.; Cords, O.; Horsburgh, C.R.; Andrews, J.R.; Pediatric TB Contact Studies Consortium. The Risk of Tuberculosis in Children after Close Exposure: A Systematic Review and Individual-Participant Meta-Analysis. Lancet 2020, 395, 973-984. [CrossRef]

15. Roya-Pabon, C.L.; Perez-Velez, C.M. Tuberculosis Exposure, Infection and Disease in Children: A Systematic Diagnostic Approach. Pneumonia 2016, 8, 23. [CrossRef] [PubMed]

16. Marais, B.J.; Gie, R.P.; Schaaf, H.S.; Hesseling, A.C.; Obihara, C.C.; Starke, J.J.; Enarson, D.A.; Donald, P.R.; Beyers, N. The Natural History of Childhood Intra-Thoracic Tuberculosis: A Critical Review of Literature from the Pre-Chemotherapy Era. Int. J. Tuberc. Lung Dis. 2004, 8, 392-402. [PubMed] 
17. Govender, I.; Karat, A.S.; Olivier, S.; Baisley, K.; Beckwith, P.; Dayi, N.; Dreyer, J.; Gareta, D.; Gunda, R.; Kielmann, K.; et al. Prevalence of Mycobacterium Tuberculosis in Sputum and Reported Symptoms among Clinic Attendees Compared to a Community Survey in Rural South Africa. Clin. Infect. Dis. Off. Publ. Infect. Dis. Soc. Am. 2021, ciab970. [CrossRef]

18. Cavallazzi, R.; Wiemken, T.; Christensen, D.; Peyrani, P.; Blasi, F.; Levy, G.; Aliberti, S.; Kelley, R.; Ramirez, J. Community-Acquired Pneumonia Organization (CAPO) Investigators. Predicting Mycobacterium Tuberculosis in Patients with Community-Acquired Pneumonia. Eur. Respir. J. 2014, 43, 178-184. [CrossRef]

19. McNally, L.M.; Jeena, P.M.; Gajee, K.; Thula, S.A.; Sturm, A.W.; Cassol, S.; Tomkins, A.M.; Coovadia, H.M.; Goldblatt, D. Effect of Age, Polymicrobial Disease, and Maternal HIV Status on Treatment Response and Cause of Severe Pneumonia in South African Children: A Prospective Descriptive Study. Lancet 2007, 369, 1440-1451. [CrossRef]

20. Whittaker, E.; López-Varela, E.; Broderick, C.; Seddon, J.A. Examining the Complex Relationship Between Tuberculosis and Other Infectious Diseases in Children. Front. Pediatr. 2019, 7, 233. [CrossRef]

21. Moore, D.P.; Klugman, K.P.; Madhi, S.A. Role of Streptococcus Pneumoniae in Hospitalization for Acute Community-Acquired Pneumonia Associated with Culture-Confirmed Mycobacterium Tuberculosis in Children: A Pneumococcal Conjugate Vaccine Probe Study. Pediatr. Infect. Dis. J. 2010, 29, 1099-1104. [CrossRef]

22. Drain, P.K.; Bajema, K.L.; Dowdy, D.; Dheda, K.; Naidoo, K.; Schumacher, S.G.; Ma, S.; Meermeier, E.; Lewinsohn, D.M.; Sherman, D.R. Incipient and Subclinical Tuberculosis: A Clinical Review of Early Stages and Progression of Infection. Clin. Microbiol. Rev. 2018, 31, e00021-18. [CrossRef]

23. Moore, D.P.; Higdon, M.M.; Hammitt, L.L.; Prosperi, C.; DeLuca, A.N.; Da Silva, P.; Baillie, V.L.; Adrian, P.V.; Mudau, A.; Deloria Knoll, M.; et al. The Incremental Value of Repeated Induced Sputum and Gastric Aspirate Samples for the Diagnosis of Pulmonary Tuberculosis in Young Children With Acute Community-Acquired Pneumonia. Clin. Infect. Dis. 2017, 64, S309-S316. [CrossRef] [PubMed] 